\title{
PREFERABILITY OF DIFFERENT WHEAT AND RICE VARIETIES TO LESSER GRAIN BORER Rhizopertha . dominica F. INFESTATION: \\ Awadalla S. S. ${ }^{1}$; A. H. Abd EI - salam ${ }^{1}$; R. B. Abo Arab ${ }^{2}$ and El - Zahraa , A. El - Maadawy ${ }^{2}$ \\ 1. Economic Entomology Department, Faculty of Agriculture, Mansoura University, Egypt . \\ 2. Plant Protection Research Institute, Sakha, Kafr El-Sheikh, Egypt.
}

\begin{abstract}
Choice and non-choice tests were carried out to determine the varietal preference of Rhizopertha dominica F. under laboratory conditions. Regarding to non-choice tests on different wheat varieties, data revealed that, Sakha 93, Sakha 94 and Shandweel were the most preferred wheat varieties, while Seds 12, Gemeiza 11 and Egypt 2 were the least preferred wheat varieties. On the other hand, Sakha 105 was the most preferred rice variety, while Giza 181and Giza 177 were the least preferred rice varieties. In respect to free choice tests on different wheat varieties, the results indicated that, Sakha 93 and Shandweel were the most preferred wheat varieties, while Seds 12, Gemeiza 11 and Egypt 2 were the least preferred wheat varieties. On the other hand, Sakha 105 was the most preferred rice variety, while Giza 181, Giza 177 and Egyptian jasmen were the least preferred rice varieties.
\end{abstract}

\section{INTRODUCTION}

The world population gets most of their daily energy needs from wheat and rice. The total grains produced (wheat and rice) in 2011 were 1.4 billion tonnes (Gt), and it is very important to store these grains without any losses to feed the ever growing global population (FAOSTAT, 2011).

The lesser grain borer, $R$. dominica, is a primary pest of stored grain in many regions of the world. The insect is injurious to cereals; breeds in corn, rice, wheat, and in other substrates containing starch. $R$. dominica is frequently captured in forest habitats and in grain storage environments. Recent studies suggest that the adults are likely to fly back and forth between agricultural and non-agricultural landscapes (Mahroof et al., 2010).

Laboratory analysis of the main components of the different wheat and rice varieties suggested that the susceptibility of these varieties to $S$. granarius infestation may be attributed to the high content of protein and low content of carbohydrate compared to resistant varieties. Susceptibility and resistance of some stored grains to certain insects have been reported by several authors (Dick and Credland 1986 ; Dongre et al., 1993 ; Kucerova and Stejskal, 1994; Ram and Singh, 1996 ; Ignacimuthu et al., 2000 ; Ali et al., 2004; Mebarkia et al. 2011 and Arthur et al., 2012).

Therefore, the aim of the present work is to study the Preferability of different wheat and rice varieties to lesser grain borer Rhizopertha . dominica F. infestation 


\section{MATERIALS AND METHODS}

Relative susceptibility of certain wheat varieties, broken wheat, rice varieties and broken rice to Rhyzopertha dominica F. were carried out under laboratory conditions at stored product pest laboratory, Sakha Agricultural Research Station. The insect pest was collected from the survey studies were maintained under laboratory conditions until use in the following investigation.

Stock culture of the insect was obtained by rearing each one on wheat (Giza 168) in an incubator maintained at $30+2^{\circ} \mathrm{C}$ and $70+5 \%$ R.H. The technique used for obtained adults of the $R$. dominica with a same age was described by Sun (1987).

The varieties used of wheat were Sakha 93, Sakha 94 , Egypt 1, Egypt 2 , Gemeza 9, Gemeza 10 , Gemeza 11, Gemeza 168, Shandwel 1 and Sedse 12 from Crop Research Institute. While, the varieties used of rice were Sakha 101, Sakha 102, Sakha 103, Sakha 104, Sakha 105, Giza 177, Giza 178, Giza 181, Giza 182 and Egyptian jasmen from Crop Research Institute.

Enough samples of wheat and rice grains of different used varieties were firstly sieved to remove stone, dust and insects. The grains were then sterilized by freezing for $24: 48 \mathrm{hr}$ at $-18:-22^{\circ} \mathrm{C}$ to be assumed freedom from any insect infestation (El-Sabaay, 1998). All grains were maintained in an incubator at a constant temperature of $29+1^{\circ} \mathrm{C}$ and $65+5 \% \mathrm{RH}$ for two weeks to obtain equilibration susceptibility of the tested wheat and rice varieties.

\section{Non-choice infestation test:}

The first experiment was conducted to study the resistant of wheat grain (crushed) and rice seeds under no choice conditions using $20 \mathrm{gm}$ of each variety in glass jars $(250 \mathrm{ml})$. Three replicates for each variety were used. Ten pairs of $R$. dominica adult beetles ( 10 day old) were introduced to each jar and allowed to mate and lay eggs on the seeds under the forementioned experimental conditions. After 10 days, the parents were removed, progeny as a number of adults, the percent of loss and damage for $R$. dominica were recorded after 60 days post-treatment. Seeds with the exist holes of insects were separated from the samples and conducted to estimate the percentage of infestation according to the following equation:

$\%$ infestation $=\quad \frac{\text { No. of infested kernels }}{\text { No. of total kernels (sound and infested) }} \times 100$

The mean weight of 1000 grain before and after infestation was determined. The difference between initial weight and final weight was calculated.

\section{Choice infestation test:}

The second infestation experiment was carried out to study the $R$. dominica infestation levels under free-choice condition. In this experiment, glass jars accommodates ten varieties of rice seeds (with three replicates) and ten varieties of wheat grain (with three replicates) were used as choice chamber. Thirty Petri dishes $(9 \mathrm{~cm}$ diameter) each contains $20 \mathrm{gm}$ of a variety was used. Three hundreds adult of tested insect (150 pairs 10 day 
old) were placed in the center part of each jar to give the insects a free choice to oviposit on any variety. The experiment was conducted at the conditions of ( $70 \%$ R.H. and $27{ }^{\circ} \mathrm{C}$ ). The parents were removed after ten days of treatment. After 60 days, the percent of damage and grain loss was estimated. Analysis of variance and Duncan (1995) were performed to rank the varieties according to their susceptibility to the insect.

\section{RESULTS AND DISCUSSION}

Choice and non-choice tests were carried out to determine the varietal preference of $R$. dominica under laboratory conditions. Four biological parameters were used as an indicator of the insect preference. These parameters were weight after damage, number of emerged progeny, the percentage of damage and the percentage of weight loss.

\section{Non-choice test:}

Data presented in Table (1) showed that the influence of different varieties of wheat on the weight after damage, number of emerged progeny, percentage of damage and percentage of weight loss caused by $R$. dominica. Regarding to the weight after damage, Seds 12 wheat variety was the highest weight after damage $(9.4 \pm 0.05 \mathrm{gm})$ followed by Egypt 2, Gemmeiza 10 and Gemmeiza $168(9.2 \pm 0.05 \mathrm{gm})$ and the lowest weight Sakha $93(8.7 \pm 0.19$ $\mathrm{gm}$ ). Meanwhile, Sakha 94 recorded the highest number of emerged progeny or the most preferred wheat variety $(51.4 \pm 7.92$ indiv.) followed by Sakha 93 and Shandwell $(27.3 \pm 0.3$ and $24.2 \pm 0.11$ indiv., respectively). Moreover, Sakha 93 recorded the higher percentage of damage $(13.0 \pm 0.2 \%)$ followed by Shandawel $(12.0 \pm 0.05 \%)$. Also, Sakha 93 and Shandweel recorded the highest percentage of weight loss with $4.3 \pm 0.1$ and $4.0 \pm 0.50 \%$, respectively. As a conclusion, data in Table (1) revealed that, Sakha 93, Sakha 94 and Shandweel were the most preferred wheat varieties, while Seds 12, Gemeiza 11 and Egypt 2 were the least preferred wheat varieties. Statistical analysis revealed that, a high significant differences were obtained for each parameter according to the different wheat varieties in non-choice test.

These results are in agreement with those of El-Syrafi et al. (2005) and they found that, the insect a chance to choose the preferred food increased mean number of eggs/Female as well as mean number of the emerged individuals. Therefore, it could consider both Sakha 8 and Sakha 93 were the most susceptible wheat varieties. 
Awadalla S. S. et al.

Table (1): Influence of different wheat varieties on number of emerged progeny, the percentage of damage and the percentage of weight loss caused by $R$. dominica according to nonchoice test.

\begin{tabular}{|l|c|c|c|c|}
\hline \multirow{2}{*}{ Varieties } & \multicolumn{4}{|c|}{ Mean + SD } \\
\cline { 2 - 5 } & $\begin{array}{c}\text { Weight after } \\
\text { damage }\end{array}$ & $\begin{array}{c}\text { No. emerged } \\
\text { progeny/ F1 }\end{array}$ & $\begin{array}{c}\text { Damage } \\
(\%)\end{array}$ & $\begin{array}{c}\text { Weight loss } \\
(\%)\end{array}$ \\
\hline Sakha 93 & $8.7 \pm 0.19 \mathrm{e}$ & $27.3 \pm 0.30 \mathrm{~b}$ & $13.0 \pm 0.20 \mathrm{a}$ & $4.3 \pm 0.10 \mathrm{a}$ \\
\hline Sakha 94 & $9.1 \pm 0.13 \mathrm{bc}$ & $51.4 \pm 7.92 \mathrm{a}$ & $10.2 \pm 1.20 \mathrm{~b}$ & $3.5 \pm 0.55 \mathrm{abc}$ \\
\hline Egypt 1 & $9.0 \pm 0.05 \mathrm{~cd}$ & $18.6 \pm 0.11 \mathrm{bcd}$ & $10.0 \pm 0.11 \mathrm{~b}$ & $3.3 \pm 0.05 \mathrm{bcd}$ \\
\hline Egypt 2 & $9.2 \pm 0.05 \mathrm{ab}$ & $13.0 \pm 0.11 \mathrm{~d}$ & $8.0 \pm 0.11 \mathrm{c}$ & $2.7 \pm 0.05 \mathrm{de}$ \\
\hline Gemeza 9 & $9.1 \pm 0.05 \mathrm{bc}$ & $15.1 \pm 0.11 \mathrm{~cd}$ & $9.0 \pm 0.05 \mathrm{bc}$ & $3.0 \pm 0.05 \mathrm{~cd}$ \\
\hline Gemeza 10 & $9.2 \pm 0.05 \mathrm{ab}$ & $13.1 \pm 0.05 \mathrm{~d}$ & $8.0 \pm 0.11 \mathrm{c}$ & $2.7 \pm 0.05 \mathrm{de}$ \\
\hline Gemeza 11 & $9.1 \pm 0.05 \mathrm{bc}$ & $15.1 \pm 0.11 \mathrm{~cd}$ & $9.0 \pm 0.05 \mathrm{bc}$ & $3.0 \pm 0.05 \mathrm{~cd}$ \\
\hline Gemeza 168 & $9.2 \pm 0.05 \mathrm{ab}$ & $13.1 \pm 0.05 \mathrm{~d}$ & $8.0 \pm 0.11 \mathrm{c}$ & $2.7 \pm 0.05 \mathrm{de}$ \\
\hline Shandwel & $8.8 \pm 0.05 \mathrm{de}$ & $24.2 \pm 0.11 \mathrm{bc}$ & $12.0 \pm 0.05 \mathrm{a}$ & $4.0 \pm 0.05 \mathrm{ab}$ \\
\hline Seds 12 & $9.4 \pm 0.05 \mathrm{a}$ & $11.8 \pm 0.11 \mathrm{~d}$ & $6.0 \pm 0.05 \mathrm{~d}$ & $2.0 \pm 0.05 \mathrm{e}$ \\
\hline
\end{tabular}

Where weight before damage $\mathbf{1} \mathbf{1 0} \mathrm{g}$

In the same column, means followed by the same letter are not significantly

different according to DMRT at 0.05 level of probability.

The obtained results in Table (2) revealed that, the influence of different varieties of rice on the weight after damage, number of emerged progeny, percentage of damage and percentage of weight loss caused by $R$. dominica. Regarding to the weight after damage, Giza 181 and Giza 177 rice varieties was the highest weight after damage $(9.9 \pm 0.05 \mathrm{gm})$ followed by Egyptian jasmen $(9.8+0.05 \mathrm{gm})$ and the lowest weight was Sakha $105(9.2 \pm 0.05$ $\mathrm{gm})$. On the other hand, Sakha 105 recorded the highest number of emerged progeny or the most preferred rice variety $(8.9 \pm 0.05$ indiv.) followed by Sakha 102 (7.2 \pm 0.05 indiv.). Moreover, Sakha 105 recorded the higher percentage of damage $(8.0 \pm 0.05 \%)$ followed by Shandawel $(7.0 \pm 0.05 \%)$. Also, Sakha 105 recorded the highest percentage of weight loss with $2.6 \pm 0.05$. As a conclusion, data in Table (2) indicated that, Sakha 105 was the most preferred rice variety, while Giza 181and Giza 177 were the least preferred rice varieties. Statistical analysis revealed that, a high significant differences were obtained for each parameter according to the different rice varieties in non-choice test. These results in non-choice test are in agreement with those of Abo Arab et al., (2006). 
Table(2): Influence of different rice varieties on number of emerged progeny, the percentage of damage and the percentage of weight loss caused by $R$. dominica according to non-choice test.

\begin{tabular}{|l|c|c|c|c|}
\hline \multirow{2}{*}{ Varieties } & \multicolumn{4}{|c|}{ Mean \pm SD } \\
\cline { 2 - 5 } & $\begin{array}{c}\text { Weight after } \\
\text { damage }\end{array}$ & $\begin{array}{c}\text { No. emerged } \\
\text { progeny/ F1 }\end{array}$ & Damage (\%) & $\begin{array}{c}\text { Weight loss } \\
(\%)\end{array}$ \\
\hline Sakha 101 & $9.4 \pm 0.05 \mathrm{~cd}$ & $5.0 \pm 0.1 \mathrm{c}$ & $6.0 \pm 0.05 \mathrm{c}$ & $2.0 \pm 0.10 \mathrm{c}$ \\
\hline Sakha 102 & $9.3 \pm 0.05 \mathrm{de}$ & $7.2 \pm 0.11 \mathrm{~b}$ & $7.0 \pm 0.05 \mathrm{~b}$ & $2.3 \pm 0.05 \mathrm{~b}$ \\
\hline Sakha 103 & $9.6 \pm 0.05 \mathrm{~b}$ & $3.5 \pm 0.28 \mathrm{e}$ & $4.0 \pm 0.05 \mathrm{e}$ & $1.3 \pm 0.05 \mathrm{e}$ \\
\hline Sakha 104 & $9.5 \pm 0.05 \mathrm{bc}$ & $4.2 \pm 0.28 \mathrm{~d}$ & $5.0 \pm 0.05 \mathrm{~d}$ & $1.6 \pm 0.05 \mathrm{~d}$ \\
\hline Sakha 105 & $9.2 \pm 0.05 \mathrm{e}$ & $8.9 \pm 0.05 \mathrm{a}$ & $8.0 \pm 0.05 \mathrm{a}$ & $2.6 \pm 0.05 \mathrm{a}$ \\
\hline Giza 177 & $9.9 \pm 0.05 \mathrm{a}$ & $1.2 \pm 0.05 \mathrm{f}$ & $1.0 \pm 0.05 \mathrm{~g}$ & $0.3 \pm 0.05 \mathrm{~g}$ \\
\hline Giza 178 & $9.6 \pm 0.05 \mathrm{~b}$ & $3.5 \pm 0.05 \mathrm{e}$ & $4.0 \pm 0.05 \mathrm{e}$ & $1.3 \pm 0.05 \mathrm{e}$ \\
\hline Giza 181 & $9.9 \pm 0.05 \mathrm{a}$ & $1.2 \pm 0.05 \mathrm{f}$ & $1.0 \pm 0.05 \mathrm{~g}$ & $0.3 \pm 0.05 \mathrm{~g}$ \\
\hline Giza 182 & $9.6 \pm 0.05 \mathrm{~b}$ & $3.5 \pm 0.05 \mathrm{e}$ & $4.0 \pm 0.05 \mathrm{e}$ & $1.3 \pm 0.05 \mathrm{e}$ \\
\hline Egyptian jasmen & $9.8 \pm 0.05 \mathrm{a}$ & $2.1 \pm 0.11 \mathrm{f}$ & $2.0 \pm 0.05 \mathrm{f}$ & $0.6 \pm 0.05 \mathrm{f}$ \\
\hline
\end{tabular}

Where weight before damage $=10 \mathrm{~g}$

In the same column, means followed by the same letter are not significantly different according to DMRT at 0.05 level of probability.

\section{Free choice test:}

Data given in Table (3) indicated that, the influence of different varieties of wheat on the weight after damage, percentage of damage and percentage of weight loss caused by $R$. dominica. Regarding to the weight after damage, Seds 12 wheat variety was the highest weight after damage $(9.6+0.05 \mathrm{gm})$ followed by Egypt 2, Gemmeiza 9, Gemmeiza 10, Gemmeiza 11 and Gemmeiza $168(9.5 \pm 0.057 \mathrm{gm})$ and the lowest weight Shandwell $(8.9 \pm 0.08 \mathrm{gm})$. Meanwhile, Sakha 93 recorded the higher percentage of damage $(11.0 \pm 0.57 \%)$ followed by Shandawel $(10.0 \pm 0.57$ $\%)$. Also, Sakha 93 and Shandweel recorded the highest percentage of weight loss with $3.6 \pm 0.11$ and $3.3 \pm 0.05 \%$, respectively. As a conclusion, data in Table (3) cleared that, Sakha 93 and Shandweel were the most preferred wheat varieties, while Seds 12, Gemeiza 11 and Egypt 2 were the least preferred wheat varieties. Statistical analysis revealed that, a high significant differences were obtained for each parameter according to the different wheat varieties in non-choice test. These results were agreement with El- Syrafi et al., (2005). 
Table (3): Influence of different wheat varieties on the percentage of weight after damage, the percentage of damage and the percentage of weight loss caused by $\boldsymbol{R}$. dominica according to free choice test.

\begin{tabular}{|l|c|c|c|}
\hline \multirow{2}{*}{ Varieties } & \multicolumn{3}{|c|}{ Mean +SD } \\
\cline { 2 - 4 } & $\begin{array}{c}\text { Weight after } \\
\text { damage }\end{array}$ & Damage (\%) & Weight loss (\%) \\
\hline Sakha 93 & $8.9 \pm 0.08 \mathrm{c}$ & $11.0 \pm 0.57 \mathrm{a}$ & $3.6 \pm 0.11 \mathrm{a}$ \\
\hline Sakha 94 & $9.4 \pm 0.057 \mathrm{ab}$ & $6.0 \pm 0.57 \mathrm{bc}$ & $2.0 \pm 0.11 \mathrm{~d}$ \\
\hline Egypt 1 & $9.3 \pm 0.057 \mathrm{~b}$ & $7.0 \pm 0.57 \mathrm{~b}$ & $2.3 \pm 0.11 \mathrm{c}$ \\
\hline Egypt 2 & $9.5 \pm 0.057 \mathrm{ab}$ & $5.0 \pm 0.57 \mathrm{~cd}$ & $1.6 \pm 0.05 \mathrm{e}$ \\
\hline Gemeza 9 & $9.5 \pm 0.057 \mathrm{ab}$ & $7.0 \pm 0.57 \mathrm{~b}$ & $2.3 \pm 0.11 \mathrm{c}$ \\
\hline Gemeza 10 & $9.5 \pm 0.057 \mathrm{ab}$ & $5.0 \pm 0.57 \mathrm{~cd}$ & $1.6 \pm 0.05 \mathrm{e}$ \\
\hline Gemeza 11 & $9.5 \pm 0.057 \mathrm{ab}$ & $5.0 \pm 0.57 \mathrm{~cd}$ & $1.6 \pm 0.05 \mathrm{e}$ \\
\hline Gemeza 168 & $9.5 \pm 0.057 \mathrm{ab}$ & $5.0 \pm 0.57 \mathrm{~cd}$ & $1.6 \pm 0.05 \mathrm{e}$ \\
\hline Shandwel & $8.9 \pm 0.08 \mathrm{c}$ & $10.0 \pm 0.57 \mathrm{a}$ & $3.3 \pm 0.05 \mathrm{~b}$ \\
\hline Seds 12 & $9.6 \pm 0.11 \mathrm{a}$ & $4.0 \pm 0.57 \mathrm{~d}$ & $1.3 \pm 0.05 \mathrm{f}$ \\
\hline
\end{tabular}

Where weight before damage $\mathbf{1} \mathbf{1 0} \mathrm{g}$

In the same column, means followed by the same letter are not significantly different according to DMRT at 0.05 level of probability.

Table (4): Influence of different rice varieties on the percentage of weight after damage, the percentage of damage and the percentage of weight loss caused by $R$. dominica according to free choice test.

\begin{tabular}{|l|c|c|c|}
\hline \multirow{2}{*}{ Varieties } & \multicolumn{3}{|c|}{ Mean \pm SD } \\
\cline { 2 - 4 } & $\begin{array}{c}\text { Weight after } \\
\text { damage }\end{array}$ & Damage (\%) & Weight loss (\%) \\
\hline Sakha 101 & $9.6 \pm 0.05 \mathrm{~cd}$ & $4.0 \pm 0.50 \mathrm{bc}$ & $1.3 \pm 0.05 \mathrm{c}$ \\
\hline Sakha 102 & $9.5 \pm 0.05 \mathrm{de}$ & $5.0 \pm 0.57 \mathrm{ab}$ & $1.6 \pm 0.05 \mathrm{~b}$ \\
\hline Sakha 103 & $9.8 \pm 0.05 \mathrm{ab}$ & $2.0 \pm 0.57 \mathrm{de}$ & $0.6 \pm 0.05 \mathrm{e}$ \\
\hline Sakha 104 & $9.7 \pm 0.05 \mathrm{bc}$ & $3.0 \pm 0.28 \mathrm{~cd}$ & $1.0 \pm 0.11 \mathrm{~d}$ \\
\hline Sakha 105 & $9.4 \pm 0.05 \mathrm{e}$ & $6.0 \pm 0.57 \mathrm{a}$ & $2.0 \pm 0.11 \mathrm{a}$ \\
\hline Giza 177 & $9.9 \pm 0.05 \mathrm{a}$ & $1.0 \pm 0.05 \mathrm{e}$ & $0.3 \pm 0.05 \mathrm{f}$ \\
\hline Giza 178 & $9.8 \pm 0.05 \mathrm{ab}$ & $2.0 \pm 0.57 \mathrm{de}$ & $0.6 \pm 0.05 \mathrm{e}$ \\
\hline Giza 181 & $9.9 \pm 0.05 \mathrm{a}$ & $1.0 \pm 0.28 \mathrm{e}$ & $0.3 \pm 0.05 \mathrm{f}$ \\
\hline Giza 182 & $9.8 \pm 0.05 \mathrm{ab}$ & $2 . \pm 0.570 \mathrm{de}$ & $0.6 \pm 0.05 \mathrm{e}$ \\
\hline Egyptian jasmen & $9.9 \pm 0.05 \mathrm{a}$ & $1.0 \pm 0.17 \mathrm{e}$ & $0.3 \pm 0.05 \mathrm{f}$ \\
\hline
\end{tabular}

Where weight before damage $=\mathbf{1 0} \mathrm{g}$

In the same column, means followed by the same letter are not significantly different according to DMRT at 0.05 level of probability.

The results represented in Table (4) showed that, the influence of different varieties of rice on the weight after damage, percentage of damage and percentage of weight loss caused by $R$. dominica. Regarding to the weight after damage, Giza 181 and Giza 177 rice varieties was the highest weight after damage $(9.9 \pm 0.05 \mathrm{gm})$ followed by Giza 178, Giza 182 and Sakha $103(9.8 \pm 0.05 \mathrm{gm})$ and the lowest weight was Sakha $105(9.4 \pm 0.05$ 
gm). Moreover, Sakha 105 recorded the higher percentage of damage (6.0 \pm $0.05 \%)$ followed by Sakha $102(5.0 \pm 0.05 \%)$. Also, Sakha 105 recorded the highest percentage of weight loss with $2.0 \pm 0.05$. As a conclusion, data in Table (4) indicated that, Sakha 105 was the most preferred rice variety, while Giza 181, Giza 177 and Egyptian jasmen were the least preferred rice varieties. Statistical analysis revealed that, a high significant differences were obtained for each parameter according to the different rice varieties in nonchoice test. Susceptibility and resistance of some stored grains to certain insects have been reported by several authors (Dick and Credland 1986 ; Dongre et al., 1993 ; Ram and Singh, 1996 ; Su et al., 1996 ; Ignacimuthu et al., 2000 and Ali et al., 2004 ).

\section{REFERENCES}

Abo Arab, R. B. S. and Samia , A. H. S. (2006). Relative susceptibility of faba bean varieties to Callosobruchus maculatus (F.). J. Pest Cont. and Environ. Sci. 14(2): 167 - 178.

Ali, S. M.; Mahgoup, S. M. ; Hamed, M. S. and Gharib, M. S. A. (2004). Infestation potential of Callosobruchus chinensis and Callosobruchus maculates on certain broadbean seed varieties . Egypt. J. Agric. Res., 82(3): $1127-1137$.

Arthur, F.H.; Ondier, G.O. and Siebennorgen, T.J. (2012). Impact of Rhysopertha dominica on quality parameters of milled rice. J. Stored Products Research, 48: 137-142.

Dick, K. M. and Credland (1986). Variation in the response of Callosobruchus maculates to a resistant variety of cowpea. J. Stored Prod. Res., 22(1): 43-48.

Dongre, T. K.; Pawar, S.E. and Harwalkar, M.R. (1993). Resistance to Callosobruchus maculates in pigeonpea and other Cajanus species. J. Stored Prod. Res., 29(4): 319-322 .

Duncan, D. B. (1995). Multiple range test and Multiple F test. Biometrics, 11: $1-4$.

El-Sabaay, T. (1998). The effectiveness of certain vegetable oils as wheat grain protectants against the granary weevil Sitophilus granarius (L.) and the lesser grain borer Rhyzopertha dominica (F.). Ph.D. Thesis, Cairo Univ., 103.

El-Syrafi, H.A.; Abdel-Baky, N.F.; Awadalla, S.S.; Gharib, M.S. and El-Said, A.Y. (2005). Varietal preference of Sitophilus oryzae and Trogoderma granarium Everts on some grain varieties of wheat and maize. J. Agric. Res., 83(2): 583-592.

FAOSTAT (2011). Food and Agricultural Organization of United Nations. http://www.faostat.fao.org Rome, Italy.

Ignacimuthu, S.; Janarthanan, S. and Balachandran (2000). Chemical basis of resistance in pulses to Callosobruchus maculates. J. Stored Prod. Res., 36(1): 89-99. 


\section{Awadalla S. S. et al.}

Kucerova, Z. and Stejskal, V. (1994). Susceptibility of wheat cultivars to postharvest losses causedc by Sitophilus granaries (L.) (Coleoptera: Curculionidae). Zeit. Pflanzennkrankheiten und Pflanzenschutz, 101(6): 641-648.

Mahroof, R.M.; Edde, P.A.; Robertson, B.; Puckette, T. and Phillips, T.W. (2010). Dispersal of Rhyzopertha dominica F. in different habitats. Environmental Entomology 39, 30 - 938.

Mebarkia, A.; Rahabe, Y.; Guechi, A.; Bouras, A. and Makhlouf, M. (2011). Susceptibility of twelve soft wheat varieties to Sitophilus granarius. J. Crop Protection, 30: 2151-2155.

Sun-Yun-Pei (1987). An analysis of some important factors affecting the results of fumigation tests on insects. Min. Agric. Exp. St. Techn. Bull. (177).

Ram, C. and Singh, V. S. (1996). Resistance to Sitphilus oryzae in wheat and associated grain characteristics. Indian J. Entomol., 58(1): 79-90 .

$$
\begin{aligned}
& \text { التفضيل الغذائى لحشرة ثاقبـة الحبوب الصغرى لأصناف مختلفة من حبوب القـح } \\
& \text { و والأرز }
\end{aligned}
$$

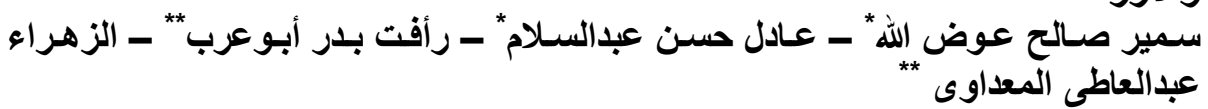

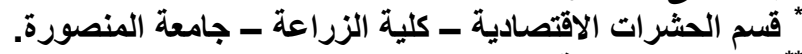

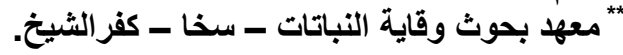

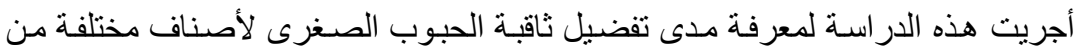

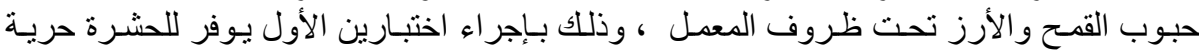

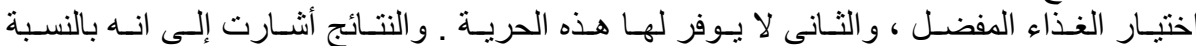

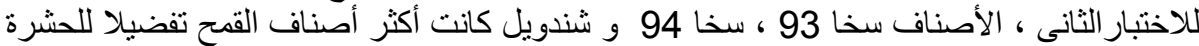

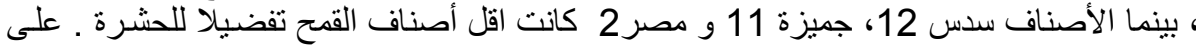

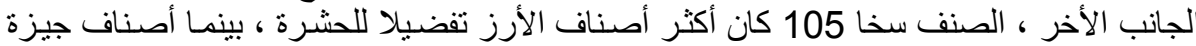

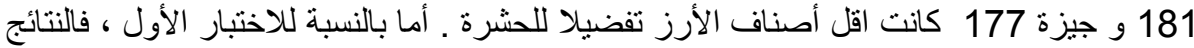

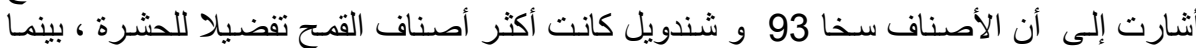

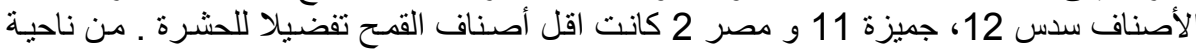

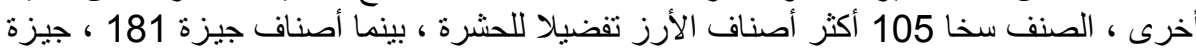

$$
\begin{aligned}
& 177 \text { و الياسمين المصرى القل أصناف الأرز تفضيلا للحشرة. }
\end{aligned}
$$

